\title{
Perspectives
}

\section{The multi-use in wind farm projects: more conflicts or a win-win opportunity?}

\author{
Denis Lacroix ${ }^{1, a}$ and Sylvain Pioch $^{2,3}$ \\ 1 IFREMER, DS, av. Jean Monnet, BP 171, 34203 Sète Cedex, France \\ 2 Egis Eau, 78 allée John Napier, 34965 Montpellier Cedex 2, France \\ 3 Dep. Biologie-Ecologie-Environnement, UMR 5175 CEFE, Université Paul Valéry, Montpellier III, route de Mende, \\ 34199 Montpellier Cedex 5, France
}

Received 10 November 2010; Accepted 15 June 2011

\begin{abstract}
The pressures on the use of the seashore are steadily rising, not only in developed countries but worldwide. Anthropogenic activity has long impacted the marine continental shelf down to a depth of approximately $-200 \mathrm{~m}$. New activities are now affecting this coastal space such as renewable energies, recreational uses and aquaculture in addition to the traditional ones of navigation or fishing. This evolution raises new sources of conflict amongst users which can require state involvement in order to manage the different stakeholders and pressure groups. However, the coastal space still offers a large potential for development for two reasons. Firstly, the physical three dimensional potential of this space enables the whole water column to be used, principally to increase the fishing productivity as in Japan. Secondly, innovative synergies can be created between socio-technical and ecological uses (a "fourth dimension") such as the eco-design of wind turbine foundations in order to create fish habitat or sea grass settlement. This new vision in "4D" for the design and the management of coastal infrastructure can potentially reduce the risk of conflict as different uses of the coastal space would not necessarily exclude one another. Indeed, several forms of synergy could be developed such as fisheries with aquaculture or biological sustainability with social acceptability. Until now, limited attempts at such an approach have been done. We suggest this is likely due to the absence of a common eco-engineering vision and the lack of experience amongst biologists and engineers in the co-construction of projects. This eco-engineering, or "green" vision, also takes into account the complexity and resilience of the ecosystem in the long term, if underwater engineered infrastructures are also "eco"-designed to increase ecological gain This new conception, for development within the coastal area, provides for an increased bio-oriented complexity to engineered structure and therefore a better resistance of the ecosystem in the long term to anthropogenic pressures and a reduction in multi-user conflicts.
\end{abstract}

Key words: Integrated coastal zone management / Marine continental shelf management / Ecological engineering / Off-shore wind farm / Aquaculture / Artificial habitat / Eco-design / Green infrastructure

\section{Introduction}

The "area" of the coastal sea is defined here as the space limited by the marine continental shelf, i.e. the volume of the sea, from the coastline to depth of approximately $-200 \mathrm{~m}$. This coastal space is approximately 27 million $\mathrm{km}^{2}$, representing $7 \%$ of the surface of the oceans, but equivalent to only $0.3 \%$ of the oceans volume. The horizontal offshore extension of this area is highly variable according to countries. At present, this multi-use space is biologically fragile although highly exploited and damaged.

Most trends affecting the sea are having an increasingly critical impact not only on the general quality of the seawater

\footnotetext{
a Corresponding author: Denis.Lacroix@ifremer.fr
}

but also on the sustainability of living resources (Pauly et al. 1998; Kavanagh 2007). Could the increasing pressure on this area be properly managed in order to secure both marine productivity and a "green" infrastructure development which could be in symbiosis with the natural ecosystem?

\section{The coastal zone: an endangered ecosystem}

\subsection{The demographic pressure on the coast}

Half of the world population is concentrated in a $50 \mathrm{~km}$ strip along the coastline; this population density is five times 
higher than that of the rest of inhabited land (Crossett et al. 2004). Among the 20 largest cities of the world, 16 are close to the sea. This concentration of mankind will grow as estimations indicate that $75 \%$ of the population will live less than $50 \mathrm{~km}$ from the sea by 2050 (Saunier and Laffitte 2007). The needs for water, food and energy will increase; in turn related waste and water pollution will progressively affect all marine ecosystems.

For example, in the Mediterranean, about 136 million people are recorded as living along the $46000 \mathrm{~km}$ of coast (The Blue Plan, Benoit and Comeau 2005). The Blue Plan expects 50 million more people by 2025 . In addition, tourism represents a huge flow of population: about 170 million tourists in 2007 , which represents $25 \%$ of the world tourism. There will probably be 312 million visitors by 2025 .

This evolution leads to a general anthropological modification of the coast. In the Mediterranean, the rate of modified coast compared to natural landscape will shift from $40 \%$ in 2000 to $50 \%$ in 2025 (Benoit and Comeau 2005). Towns, harbours, highways, airports, pipe-line, dredging, off-shore wind mills, refineries, marinas, etc., modify the ecosystem and destroy natural habitats. The amount of waste and concrete thrown into sea every year is increasing with little apparent regard for the recommendations of impact studies. Moreover, the rise of the sea level (the average rise is estimated at between 0.4 to $0.8 \mathrm{~m}$ by the end of the century according to the Intergovernmental Panel on Climate Change (IPCC 2007) will necessarily require the construction of new coastal infrastructure to protect human life and economic interests.

\subsection{The degradation of the environment and living resources}

The degradation of coastal marine ecosystems has been well established: sewage from industry and towns, organic muds, radio-nuclides, oil and coal waste, all the products and by-products of human activity finally reach the sea where several of them are integrated into the food chain. The impact is higher in closed seas such as the Mediterranean (Blondel et al. 2010).

Regarding fisheries, FAO reports that more than $2 / 3$ of the species are in a situation of full exploitation or overexploitation (FAO 2011) with a steady decline for 50 years of the global trophic index which integrates 200 species in the food chain web (Pauly and Watson 2005). If this rate is maintained, most of the targeted species for fishing will disappear before 2050 (Worm et al. 2006). Some fishing techniques, like trawling, are known to destroy habitats and related fauna in areas where spawning grounds and nurseries are present (Cury and Miserey 2008).

Every year, a longer "red" list of endangered species requiring protection is published by IUCN. National and international laws and regulations are now numerous but most of the time they give only limited results.

\subsection{The situational awareness}

An increasing number of reliable studies show that ecological services provided by marine ecosystems and particularly coastal ecosystems for human well-being, are critical: $45 \%$ of the world primary production, $50 \%$ of the oxygen production, and a sink for carbon dioxide estimated at up to about 40000 GT/year (Falkowsky et al. 1998; Ocean Resources MarineBio.org). However at present, we observe little apparent long term vision in the use of these resources, living or not.

Nevertheless, a number of states and international organizations are starting to pay more attention to fragile marine areas such as mangrove swamps or coral reefs. At the World summit of Johannesburg (2002), it was recommended: "to promote the integrated management of coasts and oceans at the national and international level, to develop networks of marine protected areas".

In 2008, the European Union provided a common maritime strategy with a consistent framework for all activities (Directive 2008/56/EC of Parliament and Council of June 17, 2008, on strategy for marine environment).This set of laws underline the importance of integrated coastal zone management, the protection of biodiversity and the correct governance for fisheries and other uses of the sea.

The recent European law about environmental liability added impact study regulations, for all EU countries. In addition, the Millenium ecosystem assessment (2005) which had focused on ecological goods and services, helped decision makers and citizens to prioritize an integrated approach for marine use. The global economic estimation of aquatic ecosystems reaches approximately some US\$ 21 billion; this value exceeds that of any other terrestrial ecosystem (Costanza et al. 1997).

This suggests that there are substantial economic benefits to be gained by preserving coastal ecosystems, not to mention social and aesthetic values that are harder to quantify. But how can we preserve, maintain or enhance the coastal ecosystem? Logically, this can be achieved by preventing the four main factors which perturb the marine ecosystem: pollution (which includes climate change due to human activities), overfishing, habitat destruction and invasive species (Jackson et al. 2001). Three of these threats concern political decisions and remedies through management and educational actions. Several solutions have been tested in various countries to remedy habitat destruction for example, by the use of artificial reefs.

\section{Green marine construction approach}

\subsection{Example of application on offshore wind farms}

The underwater structure and foundation of a wind farm may act as an "artificial reef". In fact, these new structures may induce bio-aggregation due to the phenomena of species attraction for hard substratum. Most of the time the result is an increasing aggregation of fishes and biota around the devices (Wilhelmsson et al. 2006; Wilhelmsson and Malm 2008). However, this function could have a negative impact on some species in the long term. For example, fishes may be concentrated around windmills without adequate refuge. Consequently, even if there is no concentration of biomass from surrounding areas as has been suggested (Grossman et al. 1997), the risk of increased fishing and related over-exploitation is 
clear (Inger et al. 2009). Moreover, climatic hazards may affect the concentrations of juveniles around hard substratum close to the surface, lacking complex refuge (Pastor 2008).

An improvement of the structure associated with the submerged part of offshore windmills has been proposed (Michler-Cieluch et al. 2009a). However, most of the time, the improvements are limited to a simple addition to the structure for a single specific use. For example, the solid foundations of wind turbines can serve as an attachment point for aquaculture devices notably for seaweed and mollusc culture (Buck et al. 2004; 2010), foundations of wave energy machines, with manufactured holes, have shown significant positive effects on population numbers of edible crabs Cancer pagurus (Langhamer and Wilhelmsson 2009). Moreover, even without any modification of the design, an offshore wind farm could act as a no-take zone for fishes (Punt et al. 2009).

Instead of limiting the adaptation of a wind farm to one single target in terms of ecological improvement or aquaculture production, several aims could be targeted by an eco-design of the device, from the outset of the conception of the project. This vision could lead to the design of a foundation supporting a wind turbine, which is effective for fish habitat. It could be link with a series of artificial reefs installed around an the area to create a "habitat web", with a corridor and a reservoir area.

The key idea is to take advantage of the structure itself and to integrate it into a global vision of the management of the area. The addition of complex structures should furnish a more diverse ecosystem as is observed on ship wrecks (Lindquest and Pietrafesa 1989). Ideally, the additional structures should be conceived according to the requirements of local species in order to offer effective new habitats such as bricks if crustacean are abundant locally (Koike 2001) or rocks for sea bass, etc. (Pioch 2008). Thus, artificial habitats could be designed specifically to be part of the infrastructure and its surroundings. A main target could be to provide higher diversity along the vertical structure from the sea surface (mainly for post-larvae and juveniles), to the sea bed (for adults). The ecodesign strategy consists in adding essential artificial habitats (with the ecological functions of protection, breeding, spawning and feeding) for the different species or life stages. The artificial habitat could also have structural benefits by lowering scour at the feet of the foundations through reducing the water currents and the speed of sediment transport (Fig. 1).

This set of artificial habitats on the foundations and between them, should stimulate the increase of biodiversity and biomass throughout the whole wind farm as observed in reef parks (Bombace et al. 1994; Jensen 2000; Charbonnel et al. 2002; Monteiro and Santos 2000; Santos and Monteiro 2007).

\subsection{A broad field of application today and for the future}

Numerous countries are interested in marine energy technologies because they realize their future importance. Some technologies are well known (involving tide, wind) but most of them are, as yet, experimental (involving waves, currents). Up to now, considering only the North-East Atlantic, the North Sea and the Baltic Sea area (i.e. 10 countries), 39 wind farms are functioning, more than 3000 foundations are installed on the sea bed, and 318 new projects are under study (Lacroix unpublished data). In France, marine renewable energies could represent up to $7.7 \%$ of the French target for renewable energies by 2030; offshore wind turbines represent the main technology to be developed (Lacroix and Paillard 2008). This trend, toward marine renewable energies, has been discussed for years as it raises a number of issues involving several groups of actors: the state, fishermen, tourists, associations of ecologists, local lobbies etc. (Buck et al. 2004; 2010).

Numerous other infrastructures are built in the sea or on the seashore all over the world; all with well established ecological impacts (Inger et al. 2009; Bulleri and Chapman 2010; Lapena et al. 2010). In the case of an offshore wind farm, innovative synergies have been proposed between ecological enhancement and technical, social and economical interests. The objective is to optimize the effects of underwater infrastructures to enhance the capacity for multi-use, in order to reduce conflicts. (Forst 2009; Michler-Cieluch et al. 2009a), and to balance conservation and exploitation (Queffelec et al. 2009) as well as to look for spill-over positive impacts (Petersen and Malm 2006; Punt et al. 2009). But these proposals link the main target of the wind farm (renewable energy production) to only one secondary objective, in order to take into account the demand of one stakeholder at a time: the fishermen or the aquaculturists (Michler-Cieluch et al. 2009b) or the ecologists.

The new concept is to conceive the building, the installation and the regular management of a wind farm not only for a primary user (electricity production for instance) but also for all the secondary potential users, from the outset of the project. This could help to plan a specific marine project for the widest panel of stakeholders. The idea is similar to the eco-design of construction: to maximize the positive effects (physical, biological and socio-economical) from the early stages of the project design, to enhance the environmental integration.

In this way, the needs of the energy supplier and the other potential users of the wind farm area could all be addressed.

Firstly, at present the energy supplier, owner of the wind farm, needs a very small part of the surface of the ground for the foundations and the paths for the electric cables. The managers of the project are naturally looking for good relations with all local stakeholders in order to avoid conflict. They also wish to give an ecological image of the farm, with proof of their concern for sustainable development of existing activities, such as fishing. Consequently, it is their in own interest to find the ways and means to involve all stakeholders in the project.

Traditionally, fishermen have a major role in this type of situation. They want to maintain their activity and their income. Provisions could be made for artificial reefs and reserved trawling paths between the piles from the outset of the planning of the settlement of wind turbines of the site.

The aquaculturists could also be interested in reliable moorings for pelagic-fish cages or long lines for shellfish, higher water quality, reuse of fish waste by cultured bottom fishes and an opportunity for a remote control of their devices through cameras and feeding/harvest mechanisms fixed on selected piles. Coastal tourism might be less sensitive to structural modification of the landscape as wind farms represent renewable energy with "no carbon emission". Visits of the site 


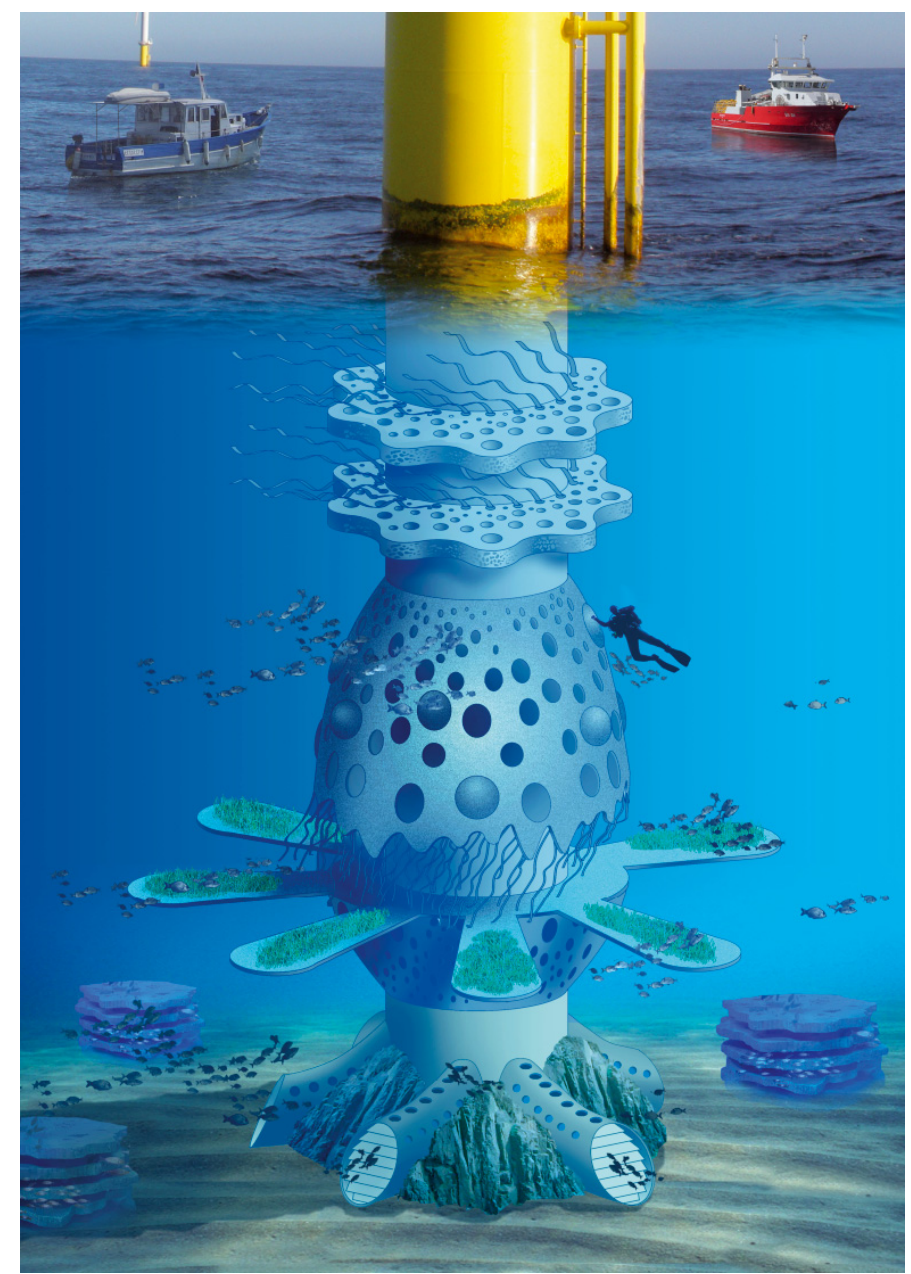

Fig. 1. Eco-designed offshore foundation for fishes, sea-grass and multi-use purposes: diving, fishing, tourism, etc. (c) Egis Eau/ Sylvain Pioch and Jean-Luc Féron.

could be proposed with marketing specifically directed at the collective approach of the planning of the project and the exemplary involvement of all stakeholders.

Scientists would be naturally interested in numerous aspects of this type of combined activity with so many opportunities for observation and monitoring on piles with electricity and data transmission facilities including video. Several fields of research could be explored: climate change, ecosystem evolution, changes in fishing capacity, aquatic species behavior, social perception of the farm and political acceptability, multidisciplinary studies, etc.

The country administration or the local authorities should notice the opportunity of a new marine protected area with numerous technical possibilities for the monitoring and the local availability of skilled people for impact assessment. Media should react positively to an innovative project as it increases the awareness of the benefits of cooperation between stakeholders and the many opportunities for education and monitoring (Fig. 2).

This type of management, which combines local interests in the short term and global interest in the long term, is actually a mixture of basic Integrated Coastal Zone Management (ICZM) principles as they emphasize the care of environmental sustainability, and the recent ecosystem based approach, which gives a more important role to human activities (Costa Pierce 2010).

It could also facilitate the acceptance and the valorization of existing wind farms by giving access to fishing, as found in Denmark, on the Horns Rev wind farm, where fishermen are allowed to fish inside the farm area. The agreement, to allow fishing, played a significant role in the social acceptability of the project (pers. comm. with director of Danish fisheries). The open consultation of all stakeholders reduces the risks of NIMBY ("Not In My Backyard") effect because "the crucial factor in NIMBY issues is not egotism, nor any other personality trait, but fair decision making that does not cause any perceived injustice" (Wolsink 2005; Breukers and Wolsink 2007). Today, it is time to consider natural issues and social dynamics as a system and not as separate disciplines (Michler-Cieluch et al. 2009a).

This approach, which has been developed here in the case study of a wind farm, could be extended to many other infrastructures at sea: harbours, sea pipe-lines, electrical cable, aquaculture devices and moorings etc. with the same double set of effects: to improve the biological acceptability of the new infrastructure and to facilitate the collective exploration 


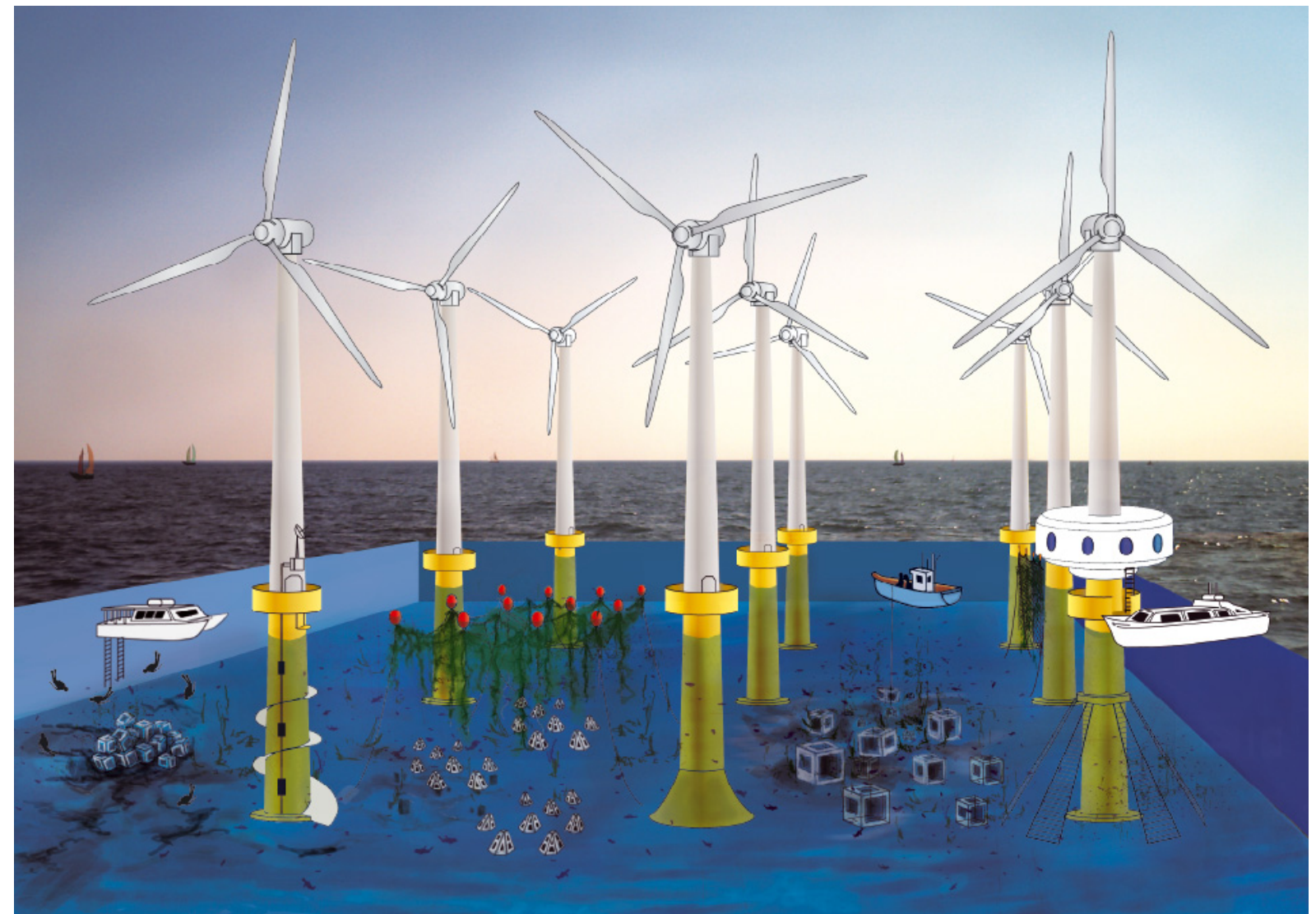

Fig. 2. Example of multi-use management of a wind farm. The wind turbine density is artificially high to facilitate the presentation of the concept. From left to right: diving, scientific studies, aquaculture, fishing, tourism. (c) Denis Lacroix, Ifremer and Malo Lacroix.

of all the ways and means to maximize the usefulness of it for all stakeholders (Pioch et al. in press). The evolution in the design and management of marine construction could contribute to a reduction in their negative impact. Actually, it has been estimated that habitat destruction remains the first cause of biodiversity loss for $67 \%$ of endangered marine species (Bœuf 2008).

\section{Conclusion}

The "blue revolution", a new way to consider the management of the sea, particularly the coastal part, is still in its infancy. Homo sapiens remains, in many ways a short-sighted predator. The challenge is to humanize the coastal region of the sea in the same way as human societies try to do on land (Jamieson 2005), slowly learning how to integrate the rules of sustainability and equity into their behavior for the sake of future generations (Gunderson and Holling 2002). On the continental shelf, the current situation is rapidly changing under the pressure of human exploitation, notably for aquaculture and in the fisheries sector. This evolution is more noticeable in Asia (FAO/NACA 2001). At the same time, an increasing number of guidelines and general recommendations have become available as numerous studies have been carried out and published on this global issue in particular from international bodies such as FAO, IUCN, European Commission, etc.
Concerning coastal zone management, decision makers now have two types of tool to improve understanding of the importance and the consequences of their choice of various scenarios. Firstly, numerous scientific disciplines have progressed significantly for the past 20 years in this field, particularly concerning ecosystem diagnosis, environment modeling, ecological engineering, impact assessment and sociology (Callon et al. 2001; Maruyama et al. 2007; Pahl-Wostl et al. 2008). Secondly, foresight analysis has progressively become a new practical tool with a broad set of methods (Schwartz 1991; van der Heijden 1996; Cornish 2004; Mermet 2005).

This approach, which combines scientific analysis and long term view, highlights the interest of more complex infrastructures at sea. At present, designers of underwater structures predict a higher resilience of ecosystems in the long term to these structures as they have been adapted or conceived in order to stimulate or protect marine life. This evolution was mainly based on the Japanese model at the end of the previous century (Nakamura 1985; Grove et al. 1989). Today, new construction models are proposed in many countries in relation to new biological targets such as those involving mitigation, restoration or recreation (Baine 2001; Bortone 2006; Thanner et al. 2006; Seaman 2007; Burt et al. 2009; Pioch et al. 2011).

This evolution could be enhanced by initiatives in the management of regional seas such as in the Mediterranean or in the Baltic Sea. The existing ambitious program of offshore wind farms could be the opportunity for a concerted action of all 
these disciplines (biology, ecology, sociology, etc.) at an international level.

Acknowledgements. The authors thank Ann Baxter for the careful reviewing of the paper.

\section{References}

Baine M., 2001, Artificial reefs: a review of their design, application, management and performance. Ocean Coast. Manage. 44, 241259.

Benoit G., Comeau A. (dir.), 2005, A sustainable future for the Mediterranean. The Blue Plan's environment and development outlook. Earthscan, Taylor \& Francis Group - Edn. de l'Aube \& Plan Bleu, Le Seuil, Paris.

Blondel J., Aronson J., Bodiou J.Y., Bœuf G., 2010, The Mediterranean region: biological diversity in space and time. 2nd edn., Oxford University Press.

Bœuf G., 2008, Quel avenir pour la biodiversité ? In: Changeux J.P., Reisse J. (Eds.). Un monde meilleur pour tous : projet réaliste ou rêve insensé ? Collège de France/Odile Jacob, Paris, pp. 47-98.

Bombace G., Fabi G., Fiorentini L., Speranza S., 1994, Analysis of the efficacy of artificial reefs located in five different areas of the Adriatic sea. Bull. Mar. Sci. 55, 559-580.

Bortone S.A., 2006, A perspective of artificial reef research, the past, the present and the future. Bull. Mar. Sci. 78, 1-8.

Breukers S., Wolsink M., 2007, Wind power implementation in changing institutional landscapes: an international comparison. Energy Policy 35, 2737-2750.

Buck B.H., Krause G., Michler-Cieluch T., Rosenthal H., 2004, Extensive open ocean aquaculture development within wind farm in Germany: the project of offshore co-management and legal constraints. Ocean Coast. Manage. 47, 95-122.

Buck B.H., Krause G., Michler-Cieluch T., 2010, Meeting the quest for spatial efficiency: progress and prospects of extensive aquaculture within offshore wind farms. Helgol. Mar. Res. 62, 269281.

Bulleri F., Chapman M.G., 2010, The introduction of coastal infrastructure as a driver of change in marine environments. J. Appl. Ecol. 47, 26-35.

Burt J., Bartholomew A., Bauman A., Saif A., Sale P.F., 2009, Coral recruitment and early benthic community development on several materials used in the construction of artificial reefs and breakwaters. J. Exp. Mar. Biol. Ecol. 373, 72-78.

Callon M., Lascoumes P., Barthes Y., 2001, La controverse comme apprentissage et traduction. In: Agir dans un monde incertain. Essai sur la démocratie technique. Coll. La couleur des idées, Le Seuil, Paris.

Charbonnel E., Serre C., Ruitton S., Harmelin J.G., Jensen A., 2002, Effects of increased habitat complexity on fish assemblages associated with large artificial reefs units. 7th Int. Conference on artificial reefs and related habitats. Oct. 1999, San Remo, Italy. ICES J. Mar. Sci. 59, S208-S213.

Cornish E., 2004, Futuring: the exploration of the future. Bethesda MD, World Future Society.

Costa-Pierce B.A., 2010, Sustainable ecological aquaculture systems: the needs for a new social contract for aquaculture development. Mar. Technol. Soc. J. 44, 88-112.

Costanza R., d'Arge R., de Groot R., Farber S., Grasso M., Hannon B., Limburg K., Naeem S., O’Neil R.V., Raskin R.G., Sutton P., van den Belt M., 1997, The value of world's ecosystem services and natural capital. Nature 387, 253-260.
Crossett K.M., Culliton T.J., Wiley P.C., Goodspeed T.R., 2004, Population trends along the coastal United States: 1980,-2008. US Dep. Commerce, NOAA, National Ocean Service. http:// www.oceanservice.noaa.gov/programs/mb/pdfs/coastal_pop_ trends_complete.pdf

Cury P., Miserey Y., 2008, Une mer sans poissons. Calmann-Lévy, Paris.

Falkowsky P.G., Barber R.T., Smetacek V., 1998, Biogeochemical controls and feedbacks on ocean primary production. Science 281, 200-206.

FAO-NACA, 2001, Aquaculture in the third Millennium. In: Subasinghe R.P., Bueno P.B., Phillips M.J., Hough C., McGladdery S.E., Arthur J.R. (Eds.). Proc. Aquaculture in the third Millenium, Bangkok, Thailand, 20-25 Feb. 2000, http:// www.fao.org/DOCREP/003/AB412E/AB412E00.HTM.

FAO, 2011, The state of world fisheries and aquaculture 2010, FAO Reports, Rome.

Forst M.F., 2009, The convergence of Integrated Coastal Zone Management and the ecosystem approach. Ocean Coast. Manage. 52, 294-306.

Grossman G.D., Jones G.P., Seaman W.J., 1997, Do artificial reefs increase regional fish production? A review of existing data. Fisheries 22, 17-23.

Grove R.S., Sonu C.J., Nakamura M., 1989, Recent Japanese trends in fishing reef design and planning. Bull. Mar. Sci. 44, 984-996.

Gunderson L.H., Holling C.S., 2002, Panarchy: understanding transformations in human and natural systems. Washington DC, Island Press.

Inger R., Attrill M.J., Bearshop S., Broderick A.C., Grecian W.J., Hodgson D.J., Mills C., Sheehan E., Votier S.C., Witt M.J., Godley B.J., 2009, Marine renewable energy: potential benefits to biodiversity? An urgent call for research. J. Appl. Ecol. 46, $1145-1153$.

Jackson J.B.C., Kirby M.X., Berger W.H., Bjorndal K.A. et al., 2001, Historical overfishing and the recent collapse of coastal ecosystems. Science 293, 629-638.

Jamieson D., 2005, Adaptation, mitigation and justice. In: SinnottArmstrong W., Howarth R.B. (Eds.). Perspectives on climate change: science, economics, politics, ethics. Oxford, Elsevier, pp. 217-248.

Jensen A.C., Collins K.J., Lockwood A.P.M. (Eds.), 2000, Artificial reefs in European seas. Dortrecht, Kluwer.

Kavanagh E., 2007, Biodiversity loss in the ocean: how bad is it? Science 316, 1281-1285.

Koike Y., 2001, Artificial reef for lobster in Tateyama station, Banda. Jpn Soc. Fish. Sci. 61.

Lacroix D., Paillard M., 2008, Energies renouvelables marines: synthèse d'une étude prospective à l'horizon 2030. Futuribles 345.

Langhamer O., Wilhelmsson D., 2009, Colonisation of fish and crabs of wave energy foundations and the effects of manufactured holes - A field experiment. Mar. Environ. Res. 68, 151-157.

Lapena B.P., Wijnberg K.M., Hulscher S.J.M.H., 2010, Environmental impact assessment of offshore wind farms: a simulation-based approach. J. Appl. Ecol. 47, 1110-1118.

Lindquest D.G., Pietrafesa L.J., 1989, Current vortices and fish aggregations: the current field and associated fishes around a tugboat in Onslow Bay, North Carolina. Bull. Mar. Sci. 44, 533-544.

Marumaya Y., Nishikido M., Tetsunari I., 2007, The rise of community wind power in Japan: Enhanced acceptance through social innovation. Energy Policy 35, 2761-2769.

Mermet L. (dir.), 2005, Etudier des écologies futures : un chantier ouvert pour les recherches prospectives environnementales. PIE Peter Lang, EcoPolis 5. 
Michler-Cieluch T., Krause G., Buck B.H., 2009a, Marine aquaculture within offshore wind farms: Social aspects of multiple-use planning. Gaia Ecol. Perspect. Sci. Soc. 18, 158-162.

Michler-Cieluch T., Krause G., Buck B.H., 2009b, Reflections on integrating operation and maintenance activities of offshore wind farms and mariculture. Ocean Coast. Manage. 52, 17-68.

Monteiro C., Santos M., 2000, Portuguese artificial reefs. Artificial reefs in European seas. In: Jensen A.C. (Eds). Kluwer, pp. 249261.

Nakamura M., 1985, Evolution of artificial fishing reefs concepts in Japan. Bull. Mar. Sci. 37, 271-278.

Pahl-Wostl C., Mostertet E., Tabara D., 2008, The growing importance of social learning in water resources management and sustainability. Ecol. Soc. 13, 24.

Pastor J., 2008, Rôle des enrochements côtiers artificiels dans la connectivité des populations, cas du sar commun (Diplodus sargus Linné, 1758) en Méditerranée nord-occidentale. Thèse dr. Univ. Perpignan/École Pratique des Hautes Études.

Pauly D., Christensen V., Dalsgaard J., Froese R., Torres F., 1998, Fishing down marine food webs. Science 279, 860-863.

Pauly D., Watson R., 2005, Background and interpretation of the marine trophic index as a measure of biodiversity. Biol. Sci. 360, 415-423.

Petersen J.K., Malm T., 2006, Offshore windmill farms: threats to or possibilities for the marine environment. Ambio 35, 75-80.

Pioch S., 2008, Les habitats artificiels: éléments de stratégie pour une gestion intégrée des zones côtières. Essai de méthodologie d'aménagement en récifs artificiels adaptés à la pêche artisanale côtière. PhD thesis, Paul Valéry Univ. Montpellier-Tokyo University of marine science and technology.

Pioch S., Kilfoyle K., Levrel H., Spieler R. (in press), Green marine construction. Proc. 3rd Int. Conference on Management of coastal recreational resources, Grosseto, Italy, Oct. 27-30, 2010.

Pioch S., Raynal J.C., Lasserre G., 2011, The artificial habitat, an evolutionary strategic tool for integrated coastal area management. In Ceccaldi H.J., Dekeyser I., Girault M., Stora G. (Eds.). Global change: mankind-marine environment interactions, Proc. 13th French-Japanese Oceanography Symposium, Marseille Sept. 2008. Springer, pp. 129-134.
Punt M.J., Groeneveld R.A., van Ierland E.C., 2009, Spatial planning of offshore wind farms: A windfall to marine environmental protection? Ecol. Econ. 69, 93-103.

Queffelec B., Cummins V., Bailly D., 2009, Integrated management of marine biodiversity in Europe: Perspectives from ICZM and the evolving EU Maritime policy framework. Mar. Policy 33, 871-877.

Santos M.N., Monteiro C.C., 2007, A fourteen-year overview of the fish assemblages and yield of the two oldest Algarve artificial reefs (Southern Portugal). Hydrobiologia 580, 225-231.

Saunier C., Laffitte P., 2007, L'apport de la science et de la technologie au développement durable ; la biodiversité : l'autre choc ? L'autre chance ? Rapport de l'OPECST, Assemblée nationale, Paris.

Schwartz P., 1991, The art of long view: planning for the future in an uncertain world. John Wiley \& Sons.

Seaman W., 2007, Artificial habitats and the restoration of degraded marine ecosystems. Hydrobiologia 580, 143-155.

Thanner S.E., McIntosh T.L., Blair S.M., 2006, Development of benthic and fish assemblages on artificial reef materials compared to adjacent natural reef assemblages in Miami, Dade County, Florida. Bull. Mar. Sci. 78, 57-70.

van der Heijden K., 1996, Scenarios: the art of strategic conversation. J. Wiley \& sons Ltd, Chichester, UK.

Wilhelmsson D., Yahya S., Ohman M., 2006, Effects of high relief structures on cold temperate fish assemblages: a field experiment. Mar. Biol. Res. 136-147.

Wilhelmsson D., Malm T., 2008, Fouling assemblages on offshore wind power plants and adjacent substrata. Estuar. Coast. Shelf Sci. 79, 459-466.

Wolsink M., 2005, Wind power implementation: The nature of public attitudes: Equity and fairness instead of "backyard motives". Renew. Sustain. Energy Rev. 11, 1188-1207.

Worm B., Barbier E.B., Beaumont N., Duffy J.E. et al., 2006, Impacts of biodiversity loss on ocean ecosystem services. Science 314, 787-790. 